\title{
Fast between Rosh Hashanah and Yom Kippur to Protest Munich and Vietnam
}

September 1972

Beerman's call in 1972 for a fast between Rosh Hashanah and Yom Kippur (September 9-18) was the result of two events that weighed heavily on him: the ongoing U.S. military action in Vietnam, including the destructive American bombing campaign that he unrelentingly opposed; and the murderous attack on the Israeli Olympic team by Palestinian terrorists in Munich on September 5-6 of that year. The pairing of these two events reflected the integration of two facets of his personality and areas of concern: the universal and the Jewish. The mode of his protest, a fast, reflected his appreciation for the "Ten Days of Repentance" between Rosh Hashanah and Yom Kippur as a time of deep introspection and self-reflection.

The increasing complacency toward the violent and meaningless destruction of human life should be of particular concern to the Jewish community during the season of the Days of Awe. We feel that it is vital to express our intense anguish over the massacre in Munich and the massive bombing of Vietnam, to engage in serious self-scrutiny regarding our past efforts to oppose such violence, as a means of strengthening our affirmation of the sacredness of human life.

We shall therefore participate in a Fast for Life for 48 hours during the week between Rosh Hashanah and Yom Kippur. We invite our fellow Jews to join us in this liquid fast and to participate with us in daily services to be held at Leo Baeck Temple during the noon hour, Sunday, Monday, and Tuesday. 


\section{COMMENTARY BY PROFESSOR STEVEN J. ROSS}

Leonard Beerman's sermons and calls to action were never meant to comfort. Rather, he wanted to create a profound sense of unease, the greater the unease the better. Complacent Jews were complicit Jews. Silence in the face of atrocities, whether committed against Jews or any human being, was simply unacceptable. For Leonard, a death was a death. He grieved as much for the five misguided Palestinians who murdered eleven Israeli Olympians at the Munich games as he did for their victims; and he grieved equally for the millions of South and North Vietnamese civilians killed by war.

A devout pacifist, Leonard Beerman hated war and the senseless destruction it brought. He cared little about laying blame; he cared only for the victims and the anguish experienced by their families and friends.

Like Moses Maimonides, Leonard did not ask congregants to be like the biblical Moses. He asked them to be the best of themselves. They could not undo the attacks at the Munich Olympics. Nor could they stop the relentless bombing of men, women, and children in Vietnam. But they could ask themselves what they could do to protest all forms of senseless violence.

In the fall of 1972, he challenged the members of Leo Baeck Temple to join him in a forty-eight-hour Fast for Life during the week between Rosh Hashanah and Yom Kippur. He wanted his congregation and friends to suffer a pain that would remind them of the pain experienced by the victims of senseless violence. This would not stop the death and destruction he so loathed, but it would be a start toward ending the complacency that allowed such vile acts to happen. 